and through the other nostril. The level left in the long leg of the $U$ shows that the whole nostril is full. A zinc wire is now placed in the solution and attached to the positive pole. The negative pole can be applied anywhere convenient. This solution should be isotonic, which point is not stressed in any article published. I have always used Dr. Friels's prescription: grape sugar, 28.5 grams, glycerin 14.4 grams, zinc sulphate 2.5 grams, and water $1,000 \mathrm{c} . \mathrm{cm}$. The results are very good in cases where the sinuses are rot affected.

\section{Twitching of Eyelids}

Dr. William Gallaugher (Hove) writes: During the past three months I have been struck by the number of cases of fibrillary twitching of the eyelids that have come under my notice. It is not always possible to see the twitching, but the patient is conscious of it and is caused considerable discomfort. It is generally referred to the medial side of the eyelids. It may be accompanied by supraorbital neuralgia, but this is not constant. In my opinion it is a sequel to the mild attacks of influenza we have had here since the New Year. As a rule it does not last more than a week, and no special treatment seems necessary except a general tonic and rest. I should be interested to know if other readers have observed any cases or if it is only a coincidence in my practice.

John Locke's Books and MSS.

Mr. JoHn G. Wilson (managing director, John and Edward Bumpus, Ltd., 350, Oxford Street, W.) writes: We are at present rxhibiting here a collection of books and MSS. beionging to John Locke the philosopher, which I think may be of special interest to you because of Locke's connexion with the medical profession. He took the degree of Bachelor of Medicine at Oxford, and the exhibition includes the Faculty granted him by the University to practise medicine (although he never proceeded to the doctor's degree); and his letters give ample evidence that he gave medical advice to his many friends throughout the rest of his life, and corresponded with Dr. Thomas Sydenham and others about difficult cases. His library includes a great number of extremely interesting early printed medical books, as well as his manuscript notebooks of treatments and prescriptions. The former include: Mathew's The Unlearned Alchymist (1660); Boyle's Sceptical Chymist; Euonymus's Thesaurus de Remediis Secretis (Leyden, 1555) ; Fioravanti's Cirurgia (Venice, 1595); La Chymie Charitable (par Demoiselle M.M., Paris, 1674); Jorden's Discourse of Naturall Bathes and Minerall Waters (London, 1632) ; and Glauber's Pharmacopoeia (Amsterdam, 1674). The whole collection is the property of Lord Lovelace, a direct descendant of Peter King, the cousin to whom Locke left this half of his library. It is on loan for exhibition until about May 20th, and I should be glad to welcome visitors at any time.

\section{Medical Gol}

There were about 130 competitors for the Manchester and District Medical Golfers' Annual Competition, which was held at Ringway on May 4th. The challenge cup, which was competed for by medal play over 18 holes, was won by Dr. C. R. Nunan (Didsbury) with a net score of 63 . Dr. Nunan also won the Walter Silver Medal for the best gross score from among those with handicaps of 10 and upwards. Dr. J. M. Norman (Pendleton) won the captain's prize. The Walter Gold Medal for the best gross score was won by Dr. A. Roy (Hulme) with 79. A prize for the best net score over the first nine holes was won by Dr. D. Gray (Bolton), and another for the best score over the second nine by Dr. L. F. Wallace (Leigh)

\section{Corrigendum}

In the correspondence pages of last week's issue, on the subject of "Bronchomoniliasis in Jersey," an unfortunate printer's error occurred.in the last paragraph of Dr. Gordon Oliver's letter. This should have read: "We are strongly of the opinion that all children who are chronic bronchitics should be subjected to a searching bacteriological test. Where no sputum is obtainable potassium iodide should be administered in large doses," etc.

\section{Vacancies}

Notifications of offices vacant in universities, medical colleges, and of vacant resident and other appointments at hospitals, will be found at pages $42,43,44,45,46,47,50$, and 51 of our advertisement columns, and advertisements as to partnerships, assistantships, and locumtenencies at pages 48 and 49 .

A short summary of vacant posts notified in the advertisement columns appears at page $\mathbf{9 2 1}$.

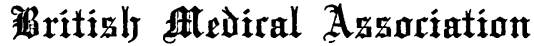

ELECTION OF 24 MEMBERS OF COUNCIL BY GROUPED BRANCHES IN THE BRITISH ISLES

The following is a list of the nominations received for 1932-3 :

\begin{tabular}{|c|c|c|}
\hline 总 & Branches in Group. & Candidates Nominated. \\
\hline A & North of England & $\begin{array}{l}\text { Dr. J. HoDson 'Newcastle. on-Tyne) } \\
\text { Dr. G. H. LOWE (Middlesbrough) }\end{array}$ \\
\hline$\overline{13}$ & Yorkshire & Dr. Peter Macdonald (York) \\
\hline$\overline{\mathrm{C}}$ & $\begin{array}{l}\text { Isle of Man. Lance. } \\
\text { shire and Cheshire }\end{array}$ & $\begin{array}{l}\text { Dr. F. J. BAILDON (Southport) } \\
\text { Dr: FrANK RADCLIFFE (Oldham) }\end{array}$ \\
\hline $\bar{D}$ & $\begin{array}{l}\text { Derbyshire. East } \\
\text { Yorks. Lincolnshire. } \\
\text { Midland }\end{array}$ & Mr. E. LEWIs LILLEY (Leicester) \\
\hline$\overline{\mathrm{E}}$ & $\begin{array}{l}\text { Bedfordshire. Cam- } \\
\text { bridge and Hunting- } \\
\text { don. Essex. Hert- } \\
\text { fordshire. Norfolk. } \\
\text { North a mptonshire. } \\
\text { Suffolk }\end{array}$ & Dr. J. W. Bone (Luton) \\
\hline $\bar{F}$ & $\begin{array}{l}\text { Berks, Bucks, and } \\
\text { Ox f or d. Birming- } \\
\text { ham. Staffordshire }\end{array}$ & Dr. E. H. SNELI (Coventry) \\
\hline$\overline{\mathrm{G}}$ & $\begin{array}{l}\text { North Wales. Shrop- } \\
\text { shire and Mid-Wales }\end{array}$ & Dr. J. R. Prytherch (Llangefni) \\
\hline H & $\begin{array}{l}\text { South Wales and Mon- } \\
\text { mouthshire }\end{array}$ & Dr. E. E. BRIERLEY (Cardiff) \\
\hline $\bar{I}$ & $\overline{\text { Metropolitan Counties }}$ & $\begin{array}{l}\text { Dr. F. W. GoonBoDr (Chelsea) } \\
\text { Mr. E. W. G. MASTERMAN (Camberwell) } \\
\text { Dr. W. PATERSON (Willesden) } \\
\text { Dr. P. B. SPURGTN (Mary'ebone) } \\
\text { Mr. H. M. STRATFORD (Kensington) } \\
\text { Dr. G. CLARR TrROTRER (City) } \\
\text { Dr. W. E. A. WORLFY (City) }\end{array}$ \\
\hline $\bar{J}$ & $\begin{array}{l}\text { Bath, Bristol and } \\
\text { Somerset. Glouces- } \\
\text { tershire. Worcester- } \\
\text { shire and Hereford- } \\
\text { shire }\end{array}$ & Dr. H. C. Bristowe (Clifton, Bristol) \\
\hline$\overline{\mathrm{K}}$ & $\begin{array}{l}\text { Dorset } \\
\text { Hants. } \\
\text { ern. Wouth-West } \\
\text { ern. Wiltshire }\end{array}$ & Dr. H. C. Jonas (Barnstaple) \\
\hline $\bar{L}$ & Southern. Surrey & $\begin{array}{l}\text { Dr. F. C. B. Gitrings (Southsea) } \\
\text { Dr. B. MORTON MACKENZIE (Dorking) }\end{array}$ \\
\hline $\bar{M}$ & Kent. Sussex & Dr. E: R. Fothergitil (Hove) \\
\hline $\bar{N}$ & $\begin{array}{l}\text { Aberdeen. } \\
\text { Northern Coundee. } \\
\text { Scotland. Perth }\end{array}$ & Dr. T. Frager (Aberdeen) \\
\hline$\overline{0}$ & Edinburgh. Fife & Dr. J. D. COMRIE (Edinburgh) \\
\hline$\overline{\mathbf{P}}$ & $\begin{array}{c}\text { Glasgow and West of } \\
\text { Scotland } \\
\text { Division) }\end{array}$ & Dr. J. HENDERSon (Glasgow) \\
\hline$\overline{\mathbf{Q}}$ & $\begin{array}{l}\text { BorderCounties. Glas- } \\
\text { gow and West of } \\
\text { Scotland (5 County } \\
\text { Divisions). Stirling }\end{array}$ & Dr. J. Livingatone LoUdon (Hamilton) \\
\hline$\overline{\mathbf{R}}$ & $\begin{array}{l}\text { Connaught. Munster } \\
\text { South-Eastern of } \\
\text { Ireland }\end{array}$ & $\begin{array}{l}\text { Dr. P. J. CASSIN (Kilkenny) } \\
\text { Dr. JoHN MILLS (Ballinasloe) }\end{array}$ \\
\hline $\mathrm{s}$ & Leinster & $\underset{\text { Dublin) }}{\text { Dr. R. Peacocke, (Blackrock, co. }}$ \\
\hline $\bar{T}$ & $\begin{array}{l}\text { Northern Ireland. } \\
\text { Monaghan and Cavan }\end{array}$ & Dr. J. C. LovGHIIDGE (Belfast) \\
\hline
\end{tabular}

The candidates referred to in the above Groups (with the exception of Groups A, I, L, and R, where contests occur), being the only candidates nominated for those Groups, are hereby declared elected Members of the Council for 1932-3.

Voting papers will be posted to all Members of the Association in Groups $A, I, L$, and $R$ from the Head Office on Saturday, May 14th; they are returnable not later than Saturday, May 21st, 1932, to the Medical Secretary, British Medical Association House, Tavistock Square, W.C.1. 